\title{
Matriarchy and the Feminist Agenda: Deconstructing the Logocentric Tenets and Posture of Nigerian Critics /Writers on Feminism
}

\author{
Chukwuka Ogbu Nwachukwu \\ Department of English and Literary Studies \\ Federal University, Ndufu-Alike, Ikwo, (FUNAI), Nigeria \\ Amaechi UnekeEnyi \\ Department of English Language and Literature \\ Ebonyi State University, Abakaliki, Nigeria
}

Received: 08-05-2015

doi:10.7575/aiac.ijclts.v.3n.3p.42
Accepted: 11-07- 2015

Published: 31-07- 2015

\begin{abstract}
This paper offers a meta-critical statement on the critical inputs of some major Nigerian male critics to the tenets and posture of feminism in a body of representative feminist creative works in Nigeria. Evincing an aggregation of these male voices the quantum of which urges feminist cautionary approach to their critical expostulations both in the creative enterprise and critical temper, the paper argues that feminism in Nigeria, of whatever shade or colouration, has become too partial, too single-voiced and therefore, too dangerous for continued male and female sanctity and the prevailing complacency in the creative,critical and even political drives of the Nigerian society.The paper in consequence challenges budding and practicing creative writers, critics and stake-holders especially in tertiary institutions in Nigeria to work to reverse or at least curtail and stall the trend as it is poised to pose intractable danger for, not only the country ,but the world at large, in terms of cohesion and the paterfamilias in the not-too-distant future.
\end{abstract}

Keywords: Matriarchy, Feminism, Deconstruction, Logocentricism

\section{Introduction}

Women's deliberate effort to resist patriarchy dates much farther back than the term "Feminism" which first entered into the English lexicon in the 1890s (Selden and Widdowson1993:263).As Nnolim (1994:)observes, "ever since that suffragette, Mary Wollstonecraft Godwin published her controversial A Vindication of the Rights of Woman"(1792)...the relationship between men and women took on a more exciting (dangerous?) turn on both political and literary fronts"(p.248).

Essentially, Feminism is reactionary. It is the explosion of an aggregation of bottled- up fuse of female frustrations regarding what they perceive as patriarchal; culturally- conditioned constructs where women are systematically subjugated and furiously fenced- in at the lowest rung of the social ladder. From the 1890s to the intense agitations of the 1960 s to the 1980s down to the present, women 'liberationists' or feminists vociferate on a coterie of grievances on perceived complexes and connivances, ostensibly by all males against all females.

The sum of Feminism and feminist activism is two-fold: a desire to work with women's issues and a political conviction that women- all women- are oppressed by men- all men- and; therefore, need to be liberated(Billing 2014).We concede that there certainly were provocations against the female prior to this activism as we will soon demonstrate.

The focus of this paper is to counter an aggregation of the logocentric views of major writers and critics on feminism. It contends that feminism is a hunter's match which has no egalitarian purpose and outlook but is rather toned to promoting and advancing Matriarchy, particularly in the Nigerian and the African space. In consequence, it recommends that creative writers as well as critics of the twenty first century should discountenance the concept and embrace more universal theories and critical approaches for constructive critical and creative engagements to cater for the egalitarian needs of the Nigerian and the African space.

\section{The Provocations}

Admittedly, a lot of male - based constructions antagonized and worked against the female, prior to the 1790s and earlier. According to Mason (2015), Thucydides recorded Pericles as legislating that the chief glory of a woman is for her not to be heard, meaning that publicity in women is detestable. Thucydides' report lends itself to the prescription of an ideology that defines the female as weak; nurturing, emotional and weak; and attributes the public sphere, special power and reason exclusively to the male (p. 1).

Aristotle in Poetics observes that "the female is female by virtue of a lack of certain qualities" (quoted in Kaplan and Anderson 2000), and proceeds to categorize the female as subject to men "but higher than slaves." St. Thomas Aquinas 
wrote that "form is masculine and matter feminine." John Donne, alluding to the Aquinas' thesis asserts:"The superior, godlike male intellect impresses its form upon the malleable, inert, female matter"(Selden and Widdowson 2000:263).Donne's poem "Go and Catch a Falling Star" (Abrams et al 1962:759-3)demonstrates his conviction that it is impossible to find a woman of virtue, who after the Smith's furnace of moral examination could be "true and fair." This line of reasoning is further pursued in his "Air and Angels"(p.772).

Selden and Widdowson further note that in pre-Mendelian times, men regarded their sperm as "the active seeds which give form to the waiting ovum which lacks identity until it receives the male "impress." Again, in Aeschylus Oresteia, Apollo wins his argument that "the mother is no parent to her child, hence "the victory of the male principle of intellect brings to an end the reign of the sensual furies and asserts patriarchy over matriarchy" (pp.263 -4).

In the Hindu religion, suttee was an ancient custom where the widow of a dead husband was buried alongside her man(ostensibly because she should not bear the touch of another man). This is akin to the practice in parts of Igboland where a widow was made to drink the muck and grime from the washed body tongue and teeth of her dead husband, and yet survive, as proof that she was innocent of the man's death. If she dared to die within a year of her husband's death, she will be denied a 'proper burial.' She killed her husband will be the verdict.

Nnolim (1994), in his article entitled "A House Divided" cites the image of Eve, Helen of Troy, Circe and the wicked sirens of mythology luring men to their deaths as evidence that the debasement of the female image in history, literature and the holy writs predate Nigerian male writers(p.258).

Where women are not made inferior, cry feminists, they are "protected," like in Europe and America, "from business competition and from the vagaries of war"(Selden and Widdowson1993:248). This melds with the feminists' grouse that they are banned from church pulpits and debarred from taking up priestly offices. They were owned by their husbands or fathers and had no independent decisions and remained anonymous, they claim.

\section{The Argument}

Feminism began in earnest as a political movement, an agitation for female enfranchisement. There was the Seneca Falls convention in New York, 1848, where Elizabeth Cady Stanton and Lucretia Mott led the convocation of the first Women's Rights Movement to demand that the American Constitution be amended to read: "We hold these truths to be self-evident, that all men and all women are created equal"(History net 2015).

Since the 1890s when the term "feminism" was first coined, it has sought to upturn the so-called "complacent" social order which feminists claim, is patriarchy-focused. Feminism has worked to enforce a belief in sexual equality. It intends to put paid to sexist domination in transforming society. In an attempt to realise these goals, feminists fall into various shades and persuasions; some are androgynous like Virginia Woolf, some lesbian like Toril Moi and Kate Millet; some are acutely individualistic like Mary Ellman and Germaine Greer while the likes of Valerie Solanas are infested with acute misandry.

Works of some of these feminists speak volumes in these veins. Virginia Woolf wants independence for her kind. She recommends a room and some money for the fructification of the female creative impulse. Using the analogy of a fictitious Shakespeare's sister, Woolf agonizes over the prospect of a female genius of Shakespeare's talents who would have come to grief and merely run to seed in Shakespeare's day, for lack of enabling conditions (Woolf 1929:1933). However, Woolf does not reckon with the fact that one mother may bear while different 'gods' fashion, as an African adage has it.

Mary Ellman in her Thinking About Women(1981) prefers to regard the ovum as daring, independent and individualistic(rather than apathetic) while the sperm is conforming and sheep-like (not enthusiastic).This finger-in-theface of the earlier Apollonian argument in Aeschylus' Oresteia is also a swipe against the Freudian and Jungian 'Phallocentric' praxes.

Valerie Solanas in her S.C.U.M. -Society for Cutting Up Men (1967) -Manifesto goes significant notches higher than Ellman. She insists that

The male is a biological accident: The $\mathrm{Y}$ (male gene) is an incomplete $\mathrm{X}$ (female gene), that is, it has an incomplete set of chromosomes. In other words, the male is an incomplete female, a walking abortion, aborted at the gene stage. (So), to be male is to be deficient (p.4).

Marigit Eichler argues that sexual promiscuity among the genders should be legalized and prostitution ordained as female advantage and opportunity to make money, using what they have.Her grouse is that prostitution is considered as bad for women and not for their male patrons. Eichler equally encourages rape for "it is a sexual act...freely engaged in by both sexes. An older woman is not guilty when she seduces a boy"(quoted in Akung 2013:129).

Tatyana Mamonova also in Akung (2013) encourages abortion, arguing that a woman should have the right to choose to become a mother or not: "I do not consider abortion as bad"(p.xix).Katty Myers equally cited in Akung (2013) champions the cause of lesbianism and advises females to eschew heterosexuality. To her, "Women can now establish a separate identity" through eroticism. To Myers, eroticism will enable women to balance sexual equation and to be more confident (p.288).

Feminism thrives on the brinksmanship of ideologues. Feminist criticism attempts to free itself from naturalized patriarchal notions of the literary and the literary critical. It refuses to be "incorporated by any approach," other than 
(thinly so) the Lacanian and Derridan Poststructuralism; instead, it opts to "disturb and subvert" all established theoretical praxes (Selden and Widdowson 1993).

Feminism's theoretic-ideological stance yields what in certain quarters is dubbed "a laughable cacophony" of voices including Marxist feminist, Black and African, Asian, Women of Colour, American, French, Irish, Black British, Gynocritics, Gynesis, Psychoanalytic, Myth, Third World/Third Wave, Deconstruction, Lesbian-feminist, Misandrist, Femalist, Motherist, Womanist, the list is interminable.

Since Sojourner Truth's speech(1867) to American feminists, women of other races have proposed alternative feminisms.Angela Davis and Alice Walker were totally influenced by Truth, resulting in the latter's proposition of Womanism.

Though feminism in Nigeria has slightly different shades from the posture of the Euro-American models, understandably as a result of the peculiarities of the African experience and cosmology, the tenets of the concept are largely the same.

African womanists feel, largely tongue- in-cheek that the western content and nuances of feminism cannot cater for their African interest in relation to her socio-cultural realities and world view. Modupe Kolawole considers womanism "more relevant to the African woman's reality and as conciliation," since "The African woman cannot divorce her struggles from the larger struggle for the emancipation of the race"(Opata and Ohaebgu 2000:105).For Aduke Adebayo (2000) "while accepting the emancipation nature of feminism, the African feminist has discarded its violent and militant approach...in carrying out their project, the African feminist critic and writer were combative for justifiable reasons"(p.4).

However, creative and critical evidence calls for a wary acceptance of Adebayo's position. Much of feminist creative and critical output in Nigeria and Africa as a whole is only slightly toned away from the all-out combative stance of western feminisms.

Elizabeth Oginin, Akung (2013)scores the point that womanism results from the fact that "the needs of the black woman are not the same as those of the white woman while equally affirming that the black woman has passed through a chain of oppressions under the system of patriarchy"(p.14). Zaynab Alkali recognizes that the African tradition frowns at the prospect of man or woman being 'single', as children are seen as the fruits of marriage and assurance for the stay of the African cosmology. This is why Lireturns to her infirm husband, Habu Adams and states that "side by side, we shall learn to walk"(Alkali 1984:120).

The quantum of feminist grouse in Nigeria at the literal level is that males appropriate discourse and write females as footnotes of male history. Agency is denied female characters in male discourse where they are treated as appendages and chattels in the treasure troves of patriarchy. This amply compares with Euripides's depiction of female characters to denigrate their sex as in "I am only a woman, a thing which the world hates"; and "no cure has been found for a woman's venom, worse than reptiles. We are a curse to man"(quoted in Mason 2015:1)Thus, women seek to upturn this trend and build female systems rooted in self-discovery, assertion and individuality; in appropriation of agency and visibility even if it means a poke of the finger in the male eye. This explains why they are largely pensive and combative in a conspiratorial bond to twist the neck of the man who dares to make fim against their matronly postures. Oko, in "Flora Nwapa's Novels"(2000)declares that "male critics are lacking in critical generosity" because of Taiwo's (1984) stance on Nwapa's Amaka in One is Enough. She cautions male critics to exercise critical restraint in matters of sex relations(p. 16).Oko further notes that Emenyonu's caption "Who Does Flora Nwapa Write for?"is fraught with the evidence that men fail or refuse to enter into woman's space in feminist contexts(p.16).

Acholonu in "Female Predicament" (1994) laments that Ekwensi's depiction of Jagua in Jagua Nana betrays "the final debasement of woman"(p.38). Again, Okereke (1994) rarefies woman for rising above her limitations successfully, mapping out survival strategies and achieving independence; citing Emecheta's Double Yoke and Destination Biafraas female craft that bear out her observations(p.83).

Contrary to the claim that Nigerian feminists are not at war with the men, Katherine Frank insists that these feminists are in full-scale war with men when viewed from the prism of the African women's relation with their men(quoted in Akung 2013).

\section{Touching the Tigress Tail: Males Respond}

African male critics have responded in various ways to the burgeoning vociferations of feminists. Some of these males are regarded as masculists or male chauvinists, in feminist parlance.A standing case is Chinweizu. Others are called tongue-in- cheek as they are middle of the road, or outright apologists. Chidilkonne is in this guild alongside Ernest Emenyonu. Other male critics of the two divides include Oladele Taiwo, Charles Nnolim, Romanus Egudu, ImeIkideh, Chidi Maduka, Obododimma Oha, Femi Ojo-Ade, Agwonorobo Eruvbetine, and a few undecided voices like Onyemaechi Udumukwu and the much younger Jonas Egbudu Akung. Males marginally regarded as democratic by feminists include Wole Soyinka, Ngugiwa Thiong'O, Isidore Okpewo, Elechi Amadi and J.P. Clark. The point, however is, probably a greater percent of female feminism activists actually distrust all male voices in the fray and marginally acclaim the woman wrappa-guild of male gender, activists.

Nnolim(1994)posits that the feminist house in Africa and in Nigeria is divided and bound to crumble; and he goes on to sort out this division into clear compartments, namely feminists, womanist/accommodationists, reactionaries middle-of -the-roaders and gyandrists (pp.250 -3). 
Feminists, for Nnolim, are the embattled writers who bully their kind into submission to present a common front against men. Nnolim mentions Chikwenye Ogunyemi and Omolara Ogundipe-Leslie with supporting voices from Juliet Okonkwo, Helen Chukwuma, and Rose Acholonu, in this guild. Womanists are feminists who do not practice radical feminism but want "meaningful union between black men and women, and will see to it that men change from their sexist stance." These groups are mainly creative writers like Flora Nwapa, Mariama Ba, Ifeoma Okoye, Zaynab Alkali, and Helen Ovbiagele. For Nnolim, their womanist stance explains why the plots of their works do not end with feminist victories (p.251).

Accommodationists recognize the primacy of men. While they seek equity in some spheres, they concede headship of the home to the men. Nnolim categorizes this group too, as mainly writers including Ifeoma Okoye, Zaynab Alkali, Helen Ovbiagele, and (reluctantly) Mariama Ba. Members of this clime want "a building together, not destruction of the home,in spite of quarrels and disagreements"(p.252).On reactionaries and middle -of-the-roaders, Nnolim notes that these either stand and wait,or use their new found voice to chastise "feminist tendencies of their fellow women" while praising their husbands to high heavens for planting, nurturing ,and raising them to their present heights; in what some other feminists would call "embarrassing self-abasement." Nnolim's clincher is that:

Zulu Sofola and Rebecca Njau are unashamedly reactionary: for forging iron cuffs to bind fellow women to steel shackles of patriarchal traditions in her major plays, and Rebecca $\mathrm{Njau}$ for afflicting her heroine with madness in her major work (p.252).

Nnolim also ruminates over gynandrists, male writers extolled by feminists for championing their cause. These include Isidore Okpe who, Sembene Ousmane, Ngugi Wa Thiong'O, Elechi Amadi, Femi Ojo-Ade and Ernest Emenyonu who are examples in both creative and critical drive to right female/ male wrongs against the female.

Nnolim's surmise is that the feminist house thus divided is unlikely to stand;much less when their standard bearer, Flora Nwapa would in an unguarded moment in $I d u$ drop, in a sober note that "A woman's ambition was marriage, a home that she could call her own, a man she could love and cherish and children to crown her marriage"(p.253).This is in spite of the established tendency for Nwapa's feminism to destroy homes, separate married men and women, and make heroines rebellious(p.254). Nnolim points out that the inevitability of the feminist house's fall is stamped by the younger generation of female writers who have "come to realise the incompleteness of woman without man"(p.259).

However, we fear that Nnolim's optimistic surmise is rather hasty as he may have been deceived by attempts to inject family in their works by a few 'new' female voices. Several of these younger writers are unstinting in their attempt to castrate the males. Adichie's (2006) heroine kills her husband whom Adichie infested with religious fanaticism and impulsive tyranny; she leaves the fire-spitting Odenigbo at the end of her novel,a mere ash of the old fire while Olanna retains her strength and matures as the war progresses to its sad end (Adichie 2007). Whatis more, Adichie recommends retaliation against male infidelity as though two wrongs could ever make a right. Olanna methodically sexes Richard in her apartment as a retaliation for Odenigbo's sexual intransigence with the village girl, Amara. To this extent, rather than being conciliatory, Adichie is unabashedly pensive and combative.

Sefi Atta's (2006) Enitan has everything good coming to her when she jilts or separates with her gentle elitist and largely to be pitied husband, Niyi who had earlier been dumped by a European wife. Again, Enitan feels happy only because her step brother cares not a hoot about their father, Sunny Taiwo's law practice and the succession question. Thus Atta's heroine is the proverbial hen that wishes that the foofoo should be full of stumpy particles.

In Swallow (2009), the heroine refuses to marry her man-Friday in spite of the latter's kindness and troubled heart. To gain independence she rather prefers to engage in dangerous swallowing of cocaine which costs her life; instead of remaining submissive to her male boss. Kane Agary's major female characters are all single, independent and comfortable people, without the complementary presence of males. This gives Zeiyifa the freedom to rollick as well she could with old men as she has no inhibitions of a father's restraining leash (Agary 2006).

What we find interestingly real and ominous is the suggestive note of alarm in Nolim's prophetic warning where, in a sober moment of pondering quietude, he warns that "Feminism which is western in orientation and individualistic in its goal, if made the ultimate good sought after by our women will eventually destroy the communal nature which is the mainstay of African societies"(p.259).

Nnolim's fear is premised on the fear that "this conflict of expectations" caused by the clash of feminism with traditional values"results in the heroines created by Rebecca Njau and Bessie Head. It is equally the cause of separation and exile where "Aissatou had to leave for New York (sic).It equally put Emecheta's heroine "intheditch."(p.259)

On his part, Maduka (2001-2002) challenges Nigerian feminists to theorize more. In "Feminism and the Nigerian Female Critic", Maduka cites M.J. C. Echeruoas suggesting that "the task for African feminism (is) to establish the general and theoretic bases for making the hard choices which Acholonu says, lies ahead: between radical dismantling of patriarchy and a zealous movement of reconciliation and compromises" (p.80).

To which we add that Nigerian feminists deploy both arsenals suggested above but their ultimate end is to dismantle patriarchy and entrench matriarchy.The warrior is not victorious until she overruns the enemy territory, dishes and metes out deserving punishment to the vanquished and establishes a reign of either terror or mercy but certainly of the victorious. 
Maduka sees feminism as a mere academic exercise for, to him, nobody has oppressed, or is oppressing anyone else in Africa, strictly on gender basis. Roles of either gender are spelt out within the African ethos. He asserts:

The idea of male domination is un-African because each sex has specific roles to play in society. Men dominate socio-political spheres of life while women are prominent in spiritual and metaphysical realms. The idea that men dominate women is false because what determines social status in Africa...is economic power and hardly gender. A woman that wields such power occupies a respectable status in society (p.85).

Maduka disapproves of feminism which "puts off the generality of the Nigerian female critics who are almost suffering from "malophobia". He further points out that feminism "tends to vitiate the male-female principle of the creative order ... ( and) pours venom on the marriage institution." The evil in this is that feminism "celebrates the individuality of the alienated female and glamorously clings to lesbianism as an enviable lifestyle" (p.82).

Maduka's alarm is based on the fact that the ideology is against the African philosophy of communality. This fact, he points out, explains why most African female writers refuse to be labeled "feminists".

Chinweizu (1990) views the blossoming of feminism as a fortuitous opportunity for males to free themselves from the shackles of matriarchy.He is convinced that though men think they lead, women are the true rulers while the males merely slave for them. In his masculinist book, Anatomy of Female Power, Chinweizu analyses the dimensions and true nature of female power. He shows that women perpetually keep men under their thumbs through manipulations and cajoleries, noting:

If the essence of power is the ability to get what one wants, then women are far from powerless.

Women do get and always did get what they want be it riches, or thrones, or the head of John the Baptist, or routine exemption from hardships and risks which their men folk are obliged to endure (p.11).

Chinweizu worries that mother power lays certain foundations in children where the boy child has a sense of heroism and self-sacrifice while the girl child is trained to imbibe narcissism which makes her to grow into a totally selfcentered person where self-sacrificing impulses are male codes of heroism, honour, and gallantry. This is why men take very big risks, die off easily and where they do not die, they lay all their exploits at the feet of these sniveling, narcissist females (p.30).

To Chinweizu, marriage is the enslavement of the man by the woman who rejoices at her exploits during the wedding after which she cages her 'animal' and hauls him home to make meals with. It is folly therefore, for a manto embark on the marriage exercise (p.30).

On the above count, Chinweizu echoes Juvenal in Satires (1967) where he suggests that the man who merely contemplates to marry, let alone actually marry a woman is mad and desirous to commit suicide:

Postumus, are you really /taking a wife? You used to be sane enough - what Fury's got into you, what snake has stung you up? Why endure such bitch tyranny when rope's available/...when all these dizzying top floor windows /Are open for you, when there are bridges handy to jump from?(p.129).

Juvenal prefers homosexuality(which is not permissible in African and Nigerian moral and metaphysical codes) to marriage with a woman, taunting Postumus with "supposing none of these (above )exits catches/your fancy, isn't it better to sleep with a pretty boy" -a proposition roundly rejected, detested and frowned upon in Nigeria.This is because boys are not termagants(and Chinweizu has noted that females are termagants), nor do they nag for little presents during coital engagements as the female does.

The materialistic nature of the female as espoused by Juvenal is further underscored by Chinweizu. On the feminist charge that men are solely sex driven in relationships with women, Chinweizu contends that every female's interest in the same is merely in the man's purse or his social pedigree(pp.50-1). This is why every courtship is a combat zone where the woman fights to establish the man's viability as a social and economic asset; love means different things for either gender: "when a woman tells a man 'I love you' she means I want you to feed me, house me, fuck me, get me great with child, and take me as your burden until I catch a better slave"'(p.43). On the other hand, when a man expresses love to the woman he means "I am eager to be your slave, and ready to do everything I can to make you satisfied and happy.” This accounts for every woman's joy soonest she hears 'I love you' from a man (p.43).

Chinweizu's disquisition on the raison detre for female conjugal engagements is probably more to the occasion in Europe and America where divorce and separation among couples is taken for granted. It is equally integral to that culture's individualism. Marital relationship in Nigeria is much more serious and deeper than Chinweizu is willing to admit. The Nigerian extended family system ensures that marriage disputes are settled between couples before they get out of hand. Couples are also wary of being branded failures in the event of a failed marriage. Chinweizu also fails to remark that the man in love overtures is equally implicated in the titillating prospect of "eating up the juicy morsel." 
Pointedly, Chinweizu is amazed by the amount of power paraded by the female yet, she cries out against this enormous bequest. He sums up his thesis on the posture and tenets of feminism arriving at the standpoint that the movement is little else than "a revolt in paradise" and as such society should be reorganized on the basis of true equality in everything including enlistment in the armed forces and in actual wars. Otherwise, Feminism will amount to nothing but "a movement of bored matriarchists, frustrated tomboys and natural termagants" each of whom has reasons for discontentment with their life of ease. Finally, Chinweizu's position is that females are not oppressed, but that they have a desire for more than their fair share:

Feminists find it politically expedient to present their aggrandizing demands in the language of oppression .But, it is hard without standing the word "oppression" on its head, to fathom how their boredom, an affliction of the leisured rich can be taken as a product of oppression (p.118).

Again, we observe that Chinweizu's pin-point assertion on "bored matriarchists" favours the Anglo-American middleclass woman, not the Nigerian woman who is hardly the leisured rich bored with excessive idleness and limitless pleasure. He however comes in handy when he notes the doublespeak in the suggestion that "such a wife is oppressed by her husband whose income makes possible her leisured life"(p.118).

Chinweizu exhorts males to borrow some cunning leaf from masculinists and relate with women on equal terms, no more standing up for ladies to sit, either in the buses or in gatherings, except if the female is either frail or old. Love should be made on equal terms so that no one solely bears the cost. This revolt in paradise offers males the chance to free themselves and begin to live longer lives.

Ikonne, according to Egudu (2000) encourages female rebellion and combative disposition. He praises Ajanupu's iconoclastic deportment in Nwapa's Efuru and enthuses that "when Ajanupu gives Gilbert a blow on the head with her mortar pestle," for accusing Efuru of adultery, the act is "symbolic of female revolt"(p.3)

Egudu, in "Flora Nwapa's Ajanupu" (2000) makes a facile contest against Ikonne on the reason for the pestle incident and on points of the symbolic representation of the attack. While Ikonne thinks this is a defence of Efuru and womanhood, Egudu, after an analysis of the incident, concludes that it is a defense of self and womanhood (p.2000:32).And we wonder: why contend over frivolous details? Why leave the fight and go for arm-twisting? The beautiful thing for Eguduand Ikonne is that a man's head stands broken by the bellicose Ajanupu, merely for talking more than his wife.

This is why both critics fall over each other to ingratiate matriarchy and the feminist agenda .Both agree (conspiratorially?)on salient matters: Ajanupu's mortar pestle attack on Gilbert is right because, just as these days are not those for keeping quiet(by females), they are equally not those in which a man can slap a woman for whatever reason, and go unchallenged by her.'(p.31)For Egudu, this is what Ajanupu has demonstrated by hitting Gilbert with the mortar pestle.

Egudu's apologia carries further: Ajanupu's falling on the floor when slapped by Gilbert is symbolic; the floor on which she falls represents the lowly position to which women have all along been subjected, and from which every woman has to struggle to rise. Ajanupu's rising followed with attacking “...signifies the possibility of women freeing themselves from the bondage of subordination and demonstrates that possibility" (p.31).

Egudu further harps on the symbolic importance of the pestle. It belonged to the kitchen, the traditional place of the woman which is inferior to the obi of the man. The use of the pestle for the attack signifies that though lowly, the kitchen could yield some instrument with which the tyrannical man may be vanquished. On these points, Egudu may be faulted. The kitchen - obi paradigm does not cohere in the order of gender roles assignment. The kitchen for the woman may only rival or compare with the ban of yams and forest of inter-tribal wars for the man. The man does not live in the forest nor does he live in the ban. In the same vein, the woman does not live in the kitchen as a domicile; it is only a domain of her economic and social power. Each of these instances is a place of site of gender role assignment.

Again, Chinweizu (1990:19) may not tap into Egudu's inferior place thesis for the woman on account of her occupation of the kitchen because "the power of the kitchen is great because it is the power over hunger ... and since the power of hunger is terrible, whatever holds power over hunger is terrible" (19).It is therefore, more to the occasion to state that Ajanupu doubled the powerful use to which the kitchen can be put, to assail Gilbert.

However, Egudu sounds mediatory toward the end. He is relieved that Efuru is a point of balance and order in traditional marital, and womanist ambitions of self-preservation, free speech and action. Ajanupu is serving alternative tradition to the feminist of separation and alienation which is anti-Africa. Egudu extols Ajanupu for providing living evidence that marriage is not necessarily a negation of women's independence and happiness; that "matrimony and equality are not mutually exclusive" (p.34).

Maduakor (2000) taunts females for being the proverbial lizard that ruined its own mother's funeral: women are the architects of their own troubles. In "Female Writer" Maduakor notes that some of Nwapa's women in Efuru are responsible for the conflict in the work:

it is the women who were first to notice signs of the new bride's prospective failure to fulfill herself as a mother. They are the first to recommend a remedy getting Adizua a second wife. It is her female neighbours who regard (Efuru) as 'a man', she is not capable of proving her womanhood by producing babies. It is Omirima who poisons the lovers' honey moon by 
insinuating contemptuously that their happiness is futile since it cannot give them children (p.124).

However, it ought to be obvious to Maduakor that this is not a stratified society where women sit at one pole and men sit at the other in an eternity of opposition. The traditional or even modern Igbo society of Nwapa's diegesis does not exist along lines of gender divides or mutual suspicion on common communal concerns.It is the feminist who arrives at the scene that draws a line where man and woman existed with mutual foibles, mutual benevolence, and mutual whims and caprices. Omirima could have come in the garb of a clowning male who might have captured the groomand bride's predicament in a mirthful song the likes of which the wag- Wordu Wakiri in The Concubine(Amadi 1966) is capable of .In addition, Omirima's revelations are in order for expertise in child-bearing matters in traditional Igbo society, is the turf of females.

Maduakor is again not satisfied with much of Nigerian women writers' style. For a count, he finds fault with Nwapa's style stating that though she uses myth in some of her crafts, she lacks local colour and "her proverbs and local idiom do not quite rhyme neatly or ring out any keen sense of their own integrity as Achebe. They tend rather to hamper the pace of the narrative"(p.126).

But, this is to be expected. Proverbs and deep idioms are actually a thing made for men who engage in high-powered polemics in Igbol and Nwapa forces herself on a terrain whose nuances she must struggle to appropriate. Whenever she uses nuances within the female space, she is always in her elements. Pros or cons we agree with Foucault's "Order of Discourse" that the holder of discourse is the owner of meaning (Kaplan and Anderson 2000:241).Men largely owned the artistry of speech in the traditional setting of Nwapa's narratology.

Maduakor also examines Emecheta's The Joys of Motherhood, The Bride Price, Double Yoke; Ifeoma Okoye's Behind the Clouds; Zaynab Alkali's Stillborn and The Virtuous Woman. He comes to the conclusion that only when Nigerian female writers balance their characterization and eschew the inordinate and vindictive urge to get even, to balance the act with men will their 'telling' attain depth and restore poetic energy to the language of their diegesis (p.138) .We can claim that the Maduakor suggestion has been amply tapped into by the likes of Chimamanda Ngozi Adichie(Yellow Sun) Sefi Atta(Everything Good), and marginally, Kane Agary (Yellow)even though they are yet to abandon "the vindictive urge to get even with men."

Charles Nnolim in a caustic article entitled "Flora Nwapa: Writer as Woman" has critiqued Nwapa's major novels and come up with a number of surmises: Nwapa's works are a travesty of the marriage institution; for her women are downright callous, egregiously immoral, and unashamedly opportunistic"(2000:117).He sees Nwapa's view of humanity, especially in One is Enough as pessimistic because both male and female characters are not role models (p.121).They make society topsy-turvy as long as they can achieve their selfish ends. None of the characters prays in time of trouble. Thus, Nwapa's society is a doomed one (p.121).

Taiwo (1986) states that Nwapa's and by extension, many Nigerian female writers' works tend to be superficial and limited in scope, and that AdaoraUlasi does not always display creative intelligence(p.137). Taiwo is convinced that "even when very occasionally Flora Nwapa attains moments of great tension her power of execution fails her."

Onukogu and Onyerionwu (2009) extol the achievement of aesthetic distance by Adichie in Purple Hibiscus and HalfOf A Yellow Sun and Sefi Atta in Everything Good Will Come. They show that the twenty-first century feminist writer has heeded the Maduakor warning to give verve to their artistry and eschew vindictive creativity (pp.110-114).

We contend that though the Adichies and the Attas achieve certain levels of artistic distance through individuating experience to reach universals; yet, their individuation of the female space is in concert with the feminist agenda to carve spaces from the blood of males if though they spatter same on walls and trample on the dead, decaying bodies.

This is why Adichie in her Purple Hibiscus, creates a warped, despicable millionaire, Eugene who is finally destroyed by his wife ; it is also why she in her Half of a Yellow Sun, emasculates an otherwise vibrant Odenigbo and denies him activity in war which is essentially, male provenance. Sefi Attaon her part in Everything good Will Come infests with silence and minority, Enitan's husband, Niyi to overturn the old order where Enitan's mother was the anonymous one while Sunny Taiwo held sway; it is equally why Enitan takes over the management of the sprawling Sunny Taiwo law concerns at the expense of the so-called illegitimate male heir who almost vegetates and wallows in inactivity. Indeed, the feminist concern is to win a war against their arch-enemy -the male; and this much more so for the younger feminist, no less for the older.

Ikheloain "In the Name of Our Sisters: Everything Good Will Come" (2008) ruminates on the conviction that "Atta assures the reader gently, ever so gently that we stand on the shoulders of giant nightmares"(p.1). We are afraid that no giant nightmare can be more gigantic than feminism in its current fashion in Nigeria.

Akung (2012), a teething feminism apologist, is even able to concede that "the female characters (in Everything Good) are very assertive and utilise all means available to them to assert their individuality("Feminist Dimensions", Abstract).This is in spite of Akung's surmise that the woman cannot continue in the space defined for her by the society; she must fight for her space both in the home and in the larger society(p.1).

Again, Akung is facile when he states that "these writers may not be classified as committed feminists," for he quickly suggests that these new novels explore the female predicament in a sexist society(our emphasis,2013:9).For him, "in spite of her education, the African woman has remained African in thought and ideology." But the above is merely 
stating neither the obvious .Neither the European nor the American feminist is African. Again, Akung's surmise on this point is acutely contentious. African ethos does not glamourize separation in marriage, retaliatory fornication, and egregious spinsterhood; nor are African men yet socialized to cry on the female's shoulder as Adichie and Atta subtly urge in their works.

\section{Conclusion}

By the very nature of the feminist ideology, we observe that the concept, in tenet and posture, is a monster with many heads each of which packs venom against patriarchy and therefore dangerous to traditional imperatives of patriarchal culture. Feminism is a hunter's match, a battle cry almost of the red tooth, a conspiratorial ploy to demarcate and decimate, to decapitate and destroy by de- rooting the eternal male/female principle rooted in conjugality and in primacy. It is an exercise in self-injury and nihilism.

Feminism in Nigeria has the potential of becoming the proverbial crocodile that eats its own egg. By urging the education and improvement of the girl child, without laying proportionate emphasis on the education of the boy child, feminism courts disaster for the future of the Nigerian and the African society. By urging women to leave their husbands and live in sin and irreverence all in the name of self-assertion, independence and individuality as represented in Nwapa's One is Enough, Sefi Atta's Everything Good, and Kane Agary's Yellow Yellow, feminism encourages the destruction of the communal base of the society and endangers the sense in family life which is the root of the African society.

By intimidating society to erect " widows' centres all over Nigeria without encouraging the erection of " widowers" centres, feminists take for granted that it is the lot of the man to die early; so, it celebrates and encourages the gradual but systematic liquidation and extirpation of males in the society. By hurtling society into creating a Ministry for Women Affairs without a corresponding ministry for men's affairs, feminists systematically entrench a culture of female preference to, and dominance over males. A ministry for women affairs without one for men affairs is unjust, partial and inhuman. It favours and feathers further, the possibility for the advancement of the feminist agenda which is the seizure of space - all the available space.

By reversing traditional male roles in their works through the representation of wicked, emasculated, weak, and silenced males, vis-a-vis the portrayal of angelic, enigmatic and superlative females, feminist creative writers like Adichie, Atta, and even the more conciliatory Ezeigbo urge the reversal of power locations, not the balancing of power. They decry the supposed male gender tyranny over the female but encourage tyranny if only the course is reversed in favour of the female. Since their gambit is to encourage and institute matriarchy, feminists have no solution for society's lack of cohesion and wellbeing as far as the gender question is concerned: One form of injustice is not a redress for another (our emphasis).

By cajoling and blackmailing society into reserving political positions -appointive and electoral -for few privileged females, often cutting-edge feminists, this demagoguery circumvents equity and level play, and flouts the rules of equality, fair principles and due process.

Nigerian feminists claim that they also take care of male issues. Ironically, central to their initial grouse was that males took care of female issues, you cannot understand the female sensibilities, they complained. Feminism cannot cater for men's issues. It is only a movement of the supposed hunted who turns around to savour the fruits of the imagined hunt, becoming the de facto hunter: where they seem weak, they feign weakened and oppressed by males; where they have strength, they bully the men (our emphasis).

All sensible women (and men) should avoid feminism. We, like Billing (2009) assert that "women who cling to feminism are not empowered, but are instead crippled cowards who are not willing to face life without the clutch that the ideology provides"(p.2).Men and women who continue to tolerate feminism diminish themselves because it is a preachment rooted in self-abasement and criminal subterfuge.

We see too that in a feminist society, "Women can never be anything but second class citizens by their own misguided, cowardly designation"(p.4).This or the graver one: feminists must succeed in destroying males, and in consequence, humanity. Feminism's vaunting ambition is as annoying as it is steeped in ridicule. It appropriates gender matters to itself and designates same 'female matters'.

Feminism is pretentious and plastic. It feints at the liberation of females. But what it has achieved in its cradle of America and Europe is the promotion of sodomy and abortion. It latches on to pornography and glamourizes eroticism and licentiousness, and like Satanism it adheres to little or no moral codes.In Nigeria, it claims to liberate and empower women. Well, it does not! What empowers women and men in Nigeria is their strength of will, hard-work,good education and the fear of God which ensures the observance of high moral precepts.

Christianity and civilization are the reasons why obnoxious traditional practices, such as the killing of twins, levirate marriage and female circumcision, etc.; were frowned at and jettisoned, not noisy feminism. Feminism is lame and cold in the greater part of Northern Nigeria, for instance and it ought to be at its crusading best there. This underscores our earlier point that religion, rather than the vociferating whim of warped demagogues design the fortunes of genders in society and you often dare not tamper with faith which is the evidence of what is not scientifically proven.

Injustice is not gender-based. It is an ill wind that blows no gender any good. Where the example of a deserving female is denied of her deserts particularly in the Nigerian space, in public as well as in private engagements and I will show you forty such males. That more males initially occupied more spaces in the public sphere was a factor of colonial, not 
traditional imperatives. Men cannot, therefore, afford to stand still, like Joshua's sun at Aijalon until late-comers take the market stands. This is analogous to asking Lagos State to wait on the pleasures of Kaura Namode before it negotiates further development.

This is why we call on Nigerian governments at the federal, state, and local levels to balance the gender equation. They should balance the call for the girl-child education with a corresponding call for the education and proper sensitization of the boy-child. Government should, as a matter of urgent national importance create a Ministry for Men Affairs which shall be married with the Ministry for Women Affairs and rebranded The Ministry for human Development and Welfare; after a gestation period of ten years.

Again, where there is a Widows' Centre, there should be a Widowers' centre; where there is a Women Development Centre, there should be a corresponding Men Relief Centre. And why not? You create for the one and leave out the other and you become partial and induce the short-changed to become riotous, eventually.

We must stop short of recommending Nietzsche's passionate plea in his incisive book Twilight of the Idols (1954:43)for a return to the rules of nature for reordering society, where the strongest, the most aggressive and the most animalistic hold down the weak and force them to do as said -the wish of the strong. The problem with the world, Nietzsche has lamented, is that priests and educators 'improve' mankind by weakening them. This reduces the purity of the strength of the strong (p.43-46).

Feminism is bereft of theory. It is couched in pedagogy and ideology. It is therefore, a freaky and brittle frame for literary exegesis. Since it is benchmarked on partiality, it should be replaced by universal and multi-voiced concepts like new historicism, postcolonialism, dialogism, globalization, and even deconstruction. New Historicism decentres monoliths and we should tap into its resources of universal discourse and jettison that brand of broken record -feminism .As we do this, we must all work for an egalitarian society that will be filled with conjugal respect for humanity without recourse to partial cleavages such as feminism represents.

Our creative writers both practising and budding should henceforth work imaginatively to destroy feminism. Let they paint pictures of feminist grand-designs that oppress men and boys which ultimately leads to rancour and the erosion of the family and the communal base of Africa's paterfamilias. Let writers of the new age show, alternatively, stack-naked powers of feminists for the tyrant that they have become. Let constructive attack and informed ridicule of the ominous noise commence. This is the challenge of the creative artist and the critic of the twenty-first century.

\section{References}

Abrams, M. H. et al Eds.(1962).The Norton Anthology of English Literature. London: W.W. Norton and Company.1.772

Acholonu, R. (1994). "The Female Predicament in the Nigerian Novel". Feminism in African Literature Essays on Criticism. Ed. Chukwuma, H. Enugu: NewGeneration Book.

Adichie,C.N.(2006).Purple hibiscus. Lagos: Farafina

Adichie, C. N. (2006). Half of a yellow Sun. Lagos: Farafina

Agary, K.(2006).Yellow-yellow. Lagos: Dtalkshop.

Akung,J.E.(2012)."Feminist Dimension in S. Atta's Everything Good Will

Come.URL:http//:www.cscanada.net.index.php/sll/article/view/j.sll1923/56320120(Retrieved June,2014(Viewed June, 2014)

Akung, J. E. “The Western Voice and Feminist Criticism”.www.sciedu.ca/1303

Amadi, E.(1966).The Concubine. London: Heinemann

Atta, S.(2006).Everything Good Will Come. Lagos: Farafina

Atta, (2007).Swallow. Lagos: Farafina

Bowen, L. (1973).Two Centuries of African English: A Survey of Non-fictional English Prose by African Writers Since 1969.London: Heinemann Educational Books.

Billing, P. (2009).“Masculinism vs. Feminism”. www. Gender/pellebilling.com (Retrieved July,2014).

Chinweizu (1990).Anatomy of female power: a masculinist's dissection of matriarchy.Lagos: Pero Press.

Chukwuma,H. (2000). “The Face of Eve: Feminism in African Literature”. Major Themes in African Literature. Eds. Opata, D. and Ohaegbu, A. Nsukka: AP Express Publishers.

Egudu, R.(2000). "Flora Nwapa's Ajanupu: The Legacy from Tradition to Feminism". Journal of Women's Studies in Africa (JOWSA):Maiden Issue.

Ellman, M.(1968).Thinking about woman .New York: Harcourt Brace Janovich

Foucault, M.(1981). “The order of discourse".Untying the text:a post- structuralist reader. Ed. Young, R. Boston: Routledge and Keegan Paul.pp.48-77

Ikheloa, I.R.(2008). "In the name of our sisters: everything good will come" (www.nigeriavillagesquare.com/...ikheloa/in-the-name-of-our-sisters-ever) viewed October,2011 
Juvenal (1967).The Sixteen Satires. London: Penguin.

Kaplan, C. and Anderson,W. D.eds.(2000). Criticism: Major Statements. ${ }^{\text {th }}$ Edition. Boston: Bedford St. Martin

Kolawole, M.(2000). "Feminine preoccupations in African literature:a theoretical appraisal". Major themes in African Literature. Eds. Opata, ,D. and Ohaegbu, Nsukka: AP Express Publishers

Maduakor, O.(2000)."The Nigerian Female Writer as Novelist”. Journal of Women Studies(JOWSA)Maiden Issue.

Maduka ,C. T. (2001-2002). "Feminism and the Nigerian Female Critic: A Meta-critical Statement". Language, Literature and Communication:A Multi- disciplinary Journal of the Arts(LLC:)2.15-35.

Mason,M.K.(2015). “Ancient Athenian women of the classical period Greeks”(www.moyak.com/papers/athenianwomen.html).retrieved June, 2015

Nietzsche,F (1954). Twilight of the Idols. Chicago: Vikings Press Inc.

Nnolim, C.(1994). "A House Divided: Feminism in African Literature”. Feminism In African Literature. Ed. Chukwuma, H. Enugu: New Generation Books.

Nnolim, C (2000).“Flora Nwapa: Writer as Woman”. Journal of Women Studies in Africa (JOWSA)1:55-75.

Nwachukwu, C.O.(2012). "Gender and war in selected Nigerian novels". Ph.D. thesis presented to the University of Calabar, Calabar, Nigeria.

Okereke, G.(1994). "Commitment to the Feminist Ideology in the Novels of Buchi Emecheta". Calabar Journal of Humanities(Ndunode) .pp.80-92.

... (1994). "The Nigerian Civil War and the Female Imagination: Buchi Emecheta's Destination Biafra”.Feminism in African Literature. Ed. Chukwuma, H. Enugu: New Generation Books.

Oko,E.(2000).’Flora Nwapa's Novels" Journal of Women Studies(JOWSA). Maiden issue.

Onukaogu, A.A. and Onyerionwu, E.(2009).21 ${ }^{\text {st }}$ century Nigerian literature: an Introductory Text. Ibadan: Kraft Books Limited.

Raman,S. and Widdowson, P.(1993).A Reader's Guide to Cotemporary Literary Theory. London: Harvester Wheatsheaf.

Solanas, V (1967).S.C.U.M.(Society for cutting up men)Manifesto.(www.womynkind.org/scum.htm).retrieved January 2013.

Taiwo, O (1984).Female Novelists of modern Africa. Basingstoke: Macmillan Publishers.

...(1986). Social experience in African literature. Enugu: Fourth Dimension Publishers

Uko, I.(2004).Gender Identity in the works of Tess Onwume. Trenton: African World Press.

Woolf, V.(1929).ARoom of Her Own. New York: Brace and Company,1989 Edition.

Woolf, v. (1933).Three Guineas. San Diego: Harcourt Brace,1996 Edition. 